\title{
Gubernur DKI Jakarta Dipilih Presiden: Sebuah Wacana yang Patut Dipertimbangkan
}

\section{Agung Wicaksono ${ }^{1}$}

\begin{abstract}
Abstrak
Tulisan ini bertujuan untuk mempertimbangkan wacana pemilihan gubernur DKI Jakarta oleh presiden. Wacana ini bisa dianggap sebagai jalan keluar dari kegaduhan politik yang ditimbulkan akibat pemilihan gubernur (pilgub) DKI Jakarta. Pilgub DKI Jakarta bermuara pada iklim politik yang tidak sehat. Polarisasi masyarakat semakin menguat dan itu tidak hanya terjadi di DKI Jakarta tetapi seluruh pelosok negeri. Masyarakat yang secara politik tidak terkait dengan DKI Jakarta pun turut ambil bagian dalam memanaskan situasi politik. Instabilitas politik di DKI Jakarta bisa berdampak pada instabilitas ekonomi. Tulisan ini berusaha menelaah wacana pemilihan gubernur DKI Jakarta oleh presiden dengan menggunakan konsep desentralisasi asimetris. Ada dua mekanisme yang bisa digunakan, yakni mekanisme "minimum demokrasi prosedural" dan "zero demokrasi prosedural". Studi literatur digunakan untuk menyintesiskan data-data dan argumentasi yang dibangun oleh penulis. Harapannya, tulisan ini bisa memberikan pemikiran dan alternatif baru dalam khazanah ilmu politik, khususnya dalam kajian mengenai pemilihan kepala daerah.
\end{abstract}

Kata Kunci: DKI Jakarta; Pilkada; Desentralisasi Asimetris

\section{Pendahuluan}

Beberapa tahun belakangan, konstelasi politik DKI Jakarta memanas. Tahun 2007 merupakan tahun dimulainya pemilihan gubernur (pilgub) DKI Jakarta secara langsung oleh rakyat. ${ }^{2}$ Kemudian,

1 Penulis adalah dosen pada Program Studi Ilmu Pemerintahan, Universitas Islam Riau

2 Pemilihan Gubernur DKI Jakarta tahun 2007 Jakarta hanya diikuti oleh dua pasangan, yakni Fauzi Bowo-Prijanto dan Adang Daradjatun-Dani Anwar. Dari tiga pilgub yang telah terjadi di Jakarta pasca dipilih langsung oleh rakyat (2007, 2012, dan 2016), pilgub ini tergolong lebih minim gejolak. Pilgub ini dimenangkan oleh Fauzi Bowo-Prijanto dengan mendapat suara sebesar $57,87 \%$. 
pilgub berlanjut di tahun 2012 yang terdiri dari enam pasang calon yang kemudian mengerucut menjadi dua pasang calon, yakni Joko Widodo-Basuki Tjahaja P. dan Fauzi Bowo-Nachrowi Ramli di putaran kedua. Kemudian, yang terakhir dan yang paling menyita perhatian adalah pilgub tahun 2017 antara Basuki Tjahaja P.-Djarot Saiful H., Anies Baswedan-Sandiaga Uno, dan Agus Harimurti Y.-Silvyana Murni. Panasnya suhu politik lima tahunan di DKI Jakarta sangat terasa dalam skala nasional, terlebih pada kanal sosial media, seperti facebook dan twitter (Buntoro, 2017; Syahputra, 2018). Peristiwa ini semakin menasbihkan DKI Jakarta sebagai episentrum perpolitikan Indonesia. DKI Jakarta bukan hanya menjadi barometer ekonomi nasional, namun juga politik nasional.

Tidak dipungkiri bahwa pilgub DKI Jakarta membangkitkan sentimen etnisitas terutama terhadap etnis Tionghoa yang dikorelasikan dengan sosok Ahok (Setijadi, 2017). Kemenangan Anies BaswedanSandiaga Uno didahului dengan berbagai rentetan peristiwa-peristiwa vital. Salah satu yang paling terangkat adalah perihal kasus "penistaan agama” oleh Basuki Tjahaja P. yang kemudian memantik resistensi dari kalangan umat Islam. Resistensi terjadi bukan hanya di kalangan umat Islam yang ada di DKI Jakarta, melainkan ke berbagai daerah se-Indonesia. Ini dibuktikan dengan aksi 212 yang kemudian muncul sebagai respons terhadap penistaan agama yang pesertanya bukan hanya dari Jakarta, melainkan dari banyak daerah di Indonesia. Polarisasi kelompok masyarakat pun terjadi secara terbuka akibat kasus ini (Hadiz, 2017; Prayogi, 2018).

Beberapa waktu belakangan, muncul isu ke permukaan bahwa Gubernur DKI Jakarta lebih baik diangkat oleh presiden. Isu ini berhembus setelah pemerintah sedang mengevaluasi semua UU yang berkaitan dengan daerah khusus dan istimewa pada tanggal 20 September 2017. Kementerian Dalam Negeri melalui Direktur Jenderal Otonomi Daerah, Soni Sumarsono mengatakan bahwa ini sedang 
masuk ke dalam proses evaluasi yang kemudian sedang meminta dan menerima berbagai usul soal mekanisme pemilihan gubernur DKI Jakarta (Beritasatu, 2017). Gubernur DKI Jakarta bisa dijadikan sebagai pejabat setingkat menteri yang diangkat dan diberhentikan oleh presiden yang sedang menjabat. Ini senada dengan usulan yang lebih dulu dilontarkan oleh wakil ketua DPR-RI 2014-2019, yakni Fahri Hamzah pada acara yang bertajuk "Rekonsiliasi Pasca Pilkada DKI" di Kompleks Parlemen RI pada tanggal 28 April 2017. Fahri mengatakan bahwa sudah selayaknya gubernur DKI Jakarta adalah orang dekatnya presiden. DKI Jakarta dapat menjadi daerah yang paling tenang dan terbebas dari persaingan politik lima tahunan, seperti yang sekarang terjadi (IDNTimes, 2017). Wacana ini menguat seiring dengan status daerah khusus yang dimiliki oleh DKI Jakarta.

Evaluasi terhadap UU Nomor 29 Tahun 2007 tentang Pemerintahan Daerah Khusus Ibu kota Jakarta yang di dalamnya turut mengatur mengenai pemilihan gubernur dan wakil gubernur DKI Jakarta bisa menjadi celah bagi wacana ini untuk bisa realisasikan. Salah satu negara yang kepala daerah untuk ibu kotanya tidak dipilih oleh rakyat secara langsung adalah Malaysia. Kepala daerah ibu kota Malaysia, yakni Kuala Lumpur disebut sebagai datuk bandar (setara walikota). Datuk bandar ini ditunjuk oleh pemerintah Malaysia melalui Kementerian Wilayah Persekutuan. Masa jabatan datuk bandar adalah selama tiga tahun (dbkl.gov.my, 2019).

Dalam tataran diskusi bidang Ilmu politik, wacana yang muncul ini menarik untuk di kaji lebih dalam. Artikel ini mencoba untuk menjelaskan argumentasi-argumentasi akademis untuk kembali mempertimbangkan DKI Jakarta tanpa pemilihan gubernur langsung oleh rakyat. Ada celah di peraturan perundang-undangan yang bisa diubah atas dasar DKI Jakarta sebagai daerah khusus ibu kota. Desentralisasi asimetris adalah konsep utama yang menjadi landasan rasional mengapa wacana ini patut untuk dipertimbangkan kembali. 
Sebagai ilmuwan politik, diskusi seputar hal ini merupakan diskusi yang menarik untuk pengembangan ilmu tentang perebutan kekuasan di ranah praktis.

\section{Desentralisasi Asimetris: Pengaturan Pemilihan Gubernur DKI Jakarta}

Desentralisasi menjadi sebuah gaya baru dalam pemerintahan yang secara komparatif dapat dilihat di berbagai belahan dunia. Desentralisasi tersebut meliputi desentralisasi politik, fiskal, maupun administrasi (Shah \& Thomson, 2004). Dalam kajian ilmu politik, konsep desentralisasi asimetris menjadi kajian yang menarik dalam beberapa tahun belakangan. Desentralisasi asimetris dapat memunculkan kreativitas dalam pembangunan daerah. Di daerah Khunsan (Republik Rakyat Tiongkok), desentralisasi asimetris bahkan muncul dari akar rumput dan menciptakan kemajuan yang signifikan bagi daerah (Chien, 2014). Desentralisasi asimetris adalah respons terhadap keberagaman yang ada di sebuah negara (Mcgarry, 2007). Di Kosovo, desentralisasi asimetris berpengaruh dalam meredakan konflik antara etnis Kosovo-Albania dan etnis Kosovo-Serbia yang acapkali bersitegang (Gioni \& Dunbar, 2010).

Indonesia adalah salah satu negara yang menerapkan konsep desentralisasi asimetris secara praktis dalam pengaturan pemerintahan di beberapa daerahnya. Desentralisasi merupakan bentuk relasi antara pusat dan daerah dalam kerangka negara kesatuan. Dalam negara kesatuan, seluruh bagian negara dikelola oleh pemerintah pusat. Karena luas wilayah dan karakter daerah yang luas, di samping keterbatasan pemerintah pusat untuk menangani seluruh urusan pemerintahan yang menjamin pelayanan publik, maka beberapa urusan diserahkan ke pemerintahan daerah (Kurniadi, 2009). Pelaksanaan desentralisasi asimetris di Indonesia dianggap sebagai solusi untuk mengatasi perbedaan geografis, keuangan, sumber daya alam, dan lain sebagainya 
di berbagai daerah di Indonesia (Nasution, 2016).

Dalam pengimplementasian di Indonesia, desentralisasi bukan hanya ada dalam bentuk simetris (penyeragaman) melainkan juga dalam bentuk yang asimetris (khusus/berbeda). Prinsip desentralisasi asimetris menawarkan suatu pendekatan untuk mendesentralisasikan pertanggungjawaban yang lebih dan dapat dilaksanakan daripada didasarkan pada pendekatan lainnya, termasuk penyeragaman (Litvack et.al., 1998). Desentralisasi asimetris itu sendiri merupakan win-win solution untuk menyelesaikan konflik antara pendukung negara kesatuan dengan gerakan separatis. Banyak negara kesatuan mempraktikkan desentralisasi asimetris, seperti Perancis, Cina, Jepang, dan Indonesia (Utomo, 2009).

Desentralisasi di Indonesia, baik simetris maupun asimetris, sangat penting untuk melihat hubungan dan proses yang berlangsung dalam rangka menemukan format pengelolaan pemerintahan yang efektif (Kuniadi, 2012). Desentralisasi menemukan sebuah format praktis yang disebut otonomi daerah. Dalam pelaksanaannya, otonomi daerah harus turut mengedepankan kekhasan masing-masing daerah. Otonomi daerah atau desentralisasi harus dilakukan dengan model keIndonesiaan (Lay, 2001).

Konsep mempertimbangkan kekhasan daerah dalam pelaksanaan otonomi daerah merupakan makna utama dari desentralisasi asimetris. Desentralisasi asimetris kemudian diimplementasikan ke dalam sebuah format yang disebut dengan otonomi khusus. Di Indonesia, otonomi khusus diterapkan di daerah khusus ibu kota Jakarta, Nangroe Aceh Darussalam, Daerah Istimewa Yogyakarta, Papua, dan Papua Barat. Desentralisasi asimetris pada kelima provinsi tersebut dilaksanakan dengan sifat kekhususan yang berbeda-beda. Seperti DKI Jakarta, kekhususannya lebih pada tata kelola pemerintahan yang khusus karena berstatus sebagai ibu kota negara. 
DKI Jakarta merupakan provinsi yang memiliki peraturan pemerintahan daerah yang berbeda. DKI Jakarta memiliki status khusus sebagai ibu kota negara Republik Indonesia. Perbedaan tersebut berkaitan dengan pengaturan struktur pemerintahan daerah dan juga dalam tatanan kepemimpinan daerah. Kekuasaan politik dan eksekutif di Jakarta terpusat pada jabatan seorang gubernur, mengingat walikota/ bupati di Jakarta hanya memiliki fungsi administrasi dan berstatus sebagai Pegawai Negeri Sipil (PNS). Walikota administratif merupakan bagian integral dari kekuasaan gubernur.

Sifat kekhususan Jakarta juga menyinggung tentang pengaturan pemilihan gubernur. Undang-undang Pilkada di DKI Jakarta (Pilgub)/ Pilkada berbeda dengan UU Pilkada yang berlaku umum di Indonesia. Perihal pilgub DKI Jakarta, pengaturannya integral dengan pengaturan pemerintahan daerah DKI Jakarta, yakni bersandar pada UU No. 29 Tahun 2007 tentang Pemerintahan Daerah Khusus Ibu Kota Jakarta. UU tersebut mengatur salah satunya tentang Pilgub DKI Jakarta yang bisa dua putaran jika salah satu pasangan calon yang maju tidak mendapat suara sebesar $50 \%+1 .^{3}$ Dalam kaitannya dengan wacana gubernur DKI Jakarta diusulkan dan ditetapkan oleh presiden, secara yuridis pengaturan mengenai suksesi kepemimpinan DKI Jakarta yang terpisah bisa menjadi celah regulasi. Pengaturan pemilihan gubernur Jakarta oleh presiden bisa diajukan tanpa mengganggu UU Pilkada yang berkaitan dengan daerah lain se-Indonesia.

3 Untuk daerah lain kecuali DKI Jakarta, tidak ada pengaturan mengenai pilkada dua putaran dikarenakan tidak ada calon yang mendapatkan suara sebesar 50\% + 1. Kemenangan calon di daerah lain hanya didasarkan pada suara pemilih terbanyak. 


\section{Sejarah Pilgub DKI Jakarta: Penunjukan Presiden, Dipilih DPRD hingga Dipilih Langsung Oleh Rakyat}

Pemilihan gubernur di DKI Jakarta memiliki sejarahnya sendiri. Di era Orde Lama, kepala daerah DKI Jakarta ditunjuk langsung oleh Pr esiden Soekarno. Tercatat mulai dari Soewirjo, Daan Jahja, Sjamsuridjal, Soediro (masih berstatus walikota) dan Soemarno S., Henk Gantung, dan Ali Sadikin (di penghujung kekuasaan Presiden Soekarno) menjabat sebagai kepala daerah DKI Jakarta (sudah berstatus sebagai gubernur). Di era Orde Baru, Ali Sadikin tetap menjadi gubernur hingga 1977. Setelah itu ada Tjokropranolo, kemudian ada Soeprapto, Wiyogo Atmodarminto, Soerjadi Soedirja, dan di akhir Orde Baru ditutup dengan Sutiyoso di tahun 1997. Proses pilgub DKI Jakarta di era Orde Baru dipilih oleh DPRD dan disetujui oleh presiden. Di era Reformasi tepatnya pada tahun 2007, DKI Jakarta dipimpin oleh Fauzi Bowo. Kemudian, ada Joko Widodo, Basuki Tjahaja Purnama, Djarot Saiful Hidayat, dan yang terakhir adalah Anies Baswedan. Di mulai dari tahun 2007, pemilihan gubernur DKI Jakarta dilaksanakan dengan dipilih langsung oleh rakyat.

Dizaman Orde Lama, kepala daerah termasukgubernur DKI Jakarta adalah jabatan pemerintahan yang proses pemilihannya berdasarkan kehendak presiden. Di masa Orde Baru berbeda lagi. Sesuai dengan UU No. 5 Tahun 1974 tentang Pokok-pokok Pemerintahan Daerah, kepala daerah dipilih oleh DPRD, namun ditetapkan oleh presiden. Mekanisme ini merupakan mekanisme yang lebih lunak dari zaman Orde Lama. DPRD melakukan penjaringan kepala daerah, kemudian mengusulkan dua orang untuk kemudian ditetapkan oleh Presiden Soeharto. Pilgub DKI Jakarta pun sama mekanismenya dalam arti tidak ada pembedaan dalam pemilihan. Pilgub DKI Jakarta sepanjang masa Orde Baru bisa dikatakan sebagai pilgub sandiwara. Proses pemilihan sejatinya telah dirancang sedemikian rupa utuk melancarkan calon 
yang direstui istana sebagai gubernur DKI Jakarta. Proses di tingkat DPRD merupakan proses yang berjalan sekadar untuk melegitimasi secara formal calon yang diinginkan istana untuk menang. Proses ini berlaku di semua daerah di Indonesia. Di hampir semua provinsi di Indonesia, termasuk DKI Jakarta, gubernur biasanya berlatar belakang sebagai perwira tinggi di ABRI yang setidaknya berpangkat jenderal bintang dua (Tasanaldy, 2007). Corak pemerintahan yang sentralistis dalah salah satu ciri utama pemerintahan Orde Baru, termasuk dalam pemilihan kepala daerah (Agustino \& Yusoff, 2010).

Di era Reformasi, muncul UU No. 22 Tahun 1999 tentang Pemerintahan Daerah. UU ini juga turut mengatur tentang Pilkada. Pilgub DKI Jakarta sama dengan daerah lainnya di Indonesia, yakni pemilihan dilakukan oleh DPRD provinsi. Selanjutnya, muncul UU No. 32 Tahun 2004 tentang Pemerintahan Daerah yang mengatur pemilihan kepala daerah langsung oleh rakyat. Namun di tahun 2007, muncul UU No. 29 Tahun 2007 tentang pemerintahan provinsi DKI Jakarta sebagai ibu kota NKRI. Sejak saat itu, pengaturan pilgub DKI Jakarta terpisah dari daerah lain. UU No. 29 Tahun 2007 menjadi pijakan utama pemilihan gubernur DKI Jakarta hingga saat ini.

\section{Gesekan Horizontal: Dampak Negatif Pilgub DKI Jakarta 2017}

Pemilihan Gubernur DKI Jakarta menjadi sorotan utama pemberitaan nasional. Hal tersebut dapat dilihat dari berbagai headline media massa lokal-nasional dan intensitas pemberitaan yang sangat tinggi (Wilson, 2017). Bukan hanya karena itu terjadi di ibu kota negara, namun isu-isu yang bergulir sepanjang perhelatan pilgub tersebut jadi pusat perhatian masyarakat Indonesia. Pilkada serentak 2017 seakan-akan hanya menyisakan DKI Jakarta sebagai gelanggang pemilihan utama. Padahal, ada 101 daerah yang melaksanakan pilkada serentak pada tangal 15 Februari 2017. 
Dalam perjalanan menuju 15 Februari 2017, suasana politik terpusat pada gerakan aksi dari berbagai elemen umat Islam yang disebut dengan Aksi Bela Islam Jilid I, Jilid II, dan yang terbesar Jilid III atau aksi 212. Gerakan tidak dinafikan muncul seiring dengan maraknya kampanye pemilihan gubernur DKI Jakarta 2017 yang diikuti oleh tiga pasang calon, Agus Harimurti Yudhoyono-Sylviana Murni, Basuki Tjahaja Purnama (Ahok)-Djarot Saiful Hidayat, dan Anies Baswedan-Sandiaga Uno. Pasangan pertama dan ketiga adalah pasangan Muslim, sedangkan pasangan kedua pasangan non-MuslimMuslim (Abdullah, 2017). Aksi Bela Islam I, II, dan III yang dilakukan tersebut merupakan critical events (peristiwa yang sangat penting) untuk melihat perkembangan keagamaan di Indonesia. Salah satunya, berkaitan dengan fragmentation of religious authority (fragmentasi atau terpecah-pecahnya otoritas keagamaan) (Burhani, 2016).

Pada tanggal 14 Oktober 2016 (Aksi Bela Islam Jilid I), ada demo yang dilakukan oleh sebagian umat Islam di Jakarta berkaitan dengan kasus penistaan agama yang dilakukan oleh Basuki Tjahaja Purnama (Ahok). Pada tanggal 4 November 2016 (Aksi Bela Islam Jilid II), ada unjuk rasa yang lebih besar dari sejumlah ormas Islam di beberapa titik di Jakarta yang kembali menuntut Basuki Tjahya Purnama (Ahok) di penjara karena dianggap telah melakukan penghinaan terhadap Islam (Pamungkas dan Oktaviani, 2017). Diketahui bahwa dari video yang beredar luas di kalangan masyarakat bahwa Ahok dianggap telah menistakan ayat suci Al-Qur'an dengan mengatakan bahwa "jangan mau dibohongi pakai ayat Al-Maidah 51". Perkataan Ahok yang notabene non Muslim memicu kemarahan dari sebagian umat Islam yang beranggapan bahwa ini adalah penistaan agama. Aksi berjilidjilid terus dilakukan umat Islam agar gubernur DKI Jakarta (yang juga merupakan calon incumbent) dipenjara. Pada tanggal 2 Desember 2016, terjadi demonstrasi besar-besaran di Jakarta yang terpusat di kawasan Monumen Nasional (Monas). Aksi tersebut sering disebut sebagai Aksi 
Bela Islam Jilid III atau Aksi 212.

Salah satu aktor gerakan yang terlibat secara aktif dalam Aksi 212 itu adalah Gerakan Nasional Pembela Fatwa-Majelis Ulama Indonesia (GNPF-MUI). Menurut GNPF-MUI, ada dua polemik utama berkaitan dengan penistaan agama oleh Ahok, yakni (1) Tafsir GNPF-MUI bahwa Ahok telah menghina ulama (pemimpin kaum Muslim) karena kalimatnya itu mengindikasikan pesan seorang ulama itu adalah "orang yang suka berbohong (penipu)"; (2) Tafsir GNPF-MUI bahwa Ahok telah menista Al-Qur'an, khususnya Surat Al-Maidah Ayat 51, dengan mengindikasikan bahwa ulama yang menggunakan ayat itu, ditujukan untuk kepentingan "menipu" umat dan atau ayat itu telah "menipu" umat (Pamungkas \& Oktaviani, 2017).

Praktis di masa itu bahkan hingga sekarang, masyarakat terpolarisasi akibat peristiwa tersebut (Lim, 2017). Peristiwa tersebut merupakan titik dimana ada gesekan horizontal terjadi di masyarakat perihal prinsip bahwa seorang Muslim harus memilih pemimpin Muslim. Masyarakat yang pro dan kontra terhadap aksi bela Islam maupun prinsip seorang Muslim harus memilih pemimpin Muslim menjadi kepala daerah. Kemudahan dan keluwesan masyarakat dalam mengakses media sosial membuat gesekan semakin terasa naik ke permukaan. Masyarakat di daerah-daerah yang notabene bukan merupakan penduduk Jakarta yang bakal memilih gubernur Jakarta juga membicarakan isu yang sama. Bahkan, banyak masyarakat yang intensitas pembicaraan di dunia nyata dan maya cenderung lebih "memikirkan" Jakarta dibanding dengan daerahnya sendiri, yang mungkin juga sedang akan melaksanakan pilkada serentak 2017 (Lim, 2017; Wilson, 2017).

Permainan politik identitas yang sangat kental terjadi di pilgub DKI Jakarta cukup menenggelamkan kampanye substantif yang seharusnya lebih ditonjolkan oleh kubu-kubu yang bertarung. Persoalan seperti 
pembangunan infrastruktur, kesehatan, pendidikan, kemiskinan, dan lain sebagainya terpinggirkan karena kampanye politik identitas yang masif terjadi setidaknya selama delapan bulan masa kampanye (Wilson, 2017). Akibat kampanye politik identitas tersebut, terjadi peningkatan sentimen masyarakat Indonesia terhadap etnis Tionghoa.

Indonesia National Survey Project (INSP) yang dikerjakan oleh ISEAS-Yusof Ishak Institute menunjukkan bahwa mayoritas responden "pribumi" mempercayai etnis Tionghoa mendominasi dan diberi keistimewaan secara ekonomi. Data menunjukkan bahwa sekitar $60 \%$ "pribumi" percaya bahwa orang Tionghoa lebih kaya secara ekonomi (Setijadi, 2017). Survei ini mengonfirmasi bahwa ada prasangka negatif terhadap pengaruh etnis Tionghoa dalam politik dan ekonomi di Indonesia dan juga banyak "pribumi” yang percaya bahwa etnis Tionghoa memiliki rasa loyalitas kebangsaan yang tidak utuh terhadap Indonesia (Setijadi, 2017).

\section{Stabilitas Politik dan Stabilitas Ekonomi}

Ada sebuah idiom dimana stabilitas ekonomi ditentukan dari stabilitas politik. Stabilitas politik menciptakan rasa nyaman dan aman bagi para investor untuk berinvestasi. Jika stabilitas politik tidak hadir, maka sektor ekonomi pasti menjadi korban. Ketidakstabilan politik (dan keamanan) dapat menurunkan pertumbuhan ekonomi, meningkatkan pengangguran dan gelombang PHK, tidak terkendalinya inflasi, dan peningkatan angka kemiskinan. Berdasarkan hal tersebut, dapat dinyatakan betapa pentingnya kestabilan dan keamanan dalam pembangunan suatu negara. Kesimpulannya adalah bahwa stabilitas politik merupakan necessary condition bagi pembangunan ekonomi (Ambarita, 2013). Ada korelasi yang nyata antara stabilitas politik dan pertumbuhan ekonomi di suatu negara (Feng, 1997).

Krisis multi dimensi tahun 1998 adalah salah satu contoh nyata keterkaitan antara stabilitas politik dan pertumbuhan ekonomi. Di 
awal Reformasi, kebijakan target inflasi Indonesia gagal pada tahun 2000-2002. Salah satu penyebabnya adalah kondisi perpolitikan yang tidak pasti (Ilham \& Siregar, 2016). Politik domestik juga menentukan stabilitas dan keterbukaan ekonomi internasional (Milner, 1998). Penelitian yang dilakukan oleh Alesina (dkk) yang mengambil sampel di 113 negara pada periode 1950-1982 bahwa negara yang politik dan pemerintahannya tidak stabil cenderung lebih rendah pertumbuhan ekonominya (Alesina et.al., 1996).

Sistem politik yang stabil dapat bertindak sebagai katalis untuk pertumbuhan ekonomi. Ketidakstabilan politik sering mengarah ke pertumbuhan ekonomi yang lebih lambat. Namun, para analis berbeda tentang saluran-saluran dimana ketidakstabilan politik diterjemahkan ke dalam pertumbuhan ekonomi yang lebih lambat (Younis et.al., 2008). Dalam sebuah artikel, dijelaskan bahwa ukuran ketidakstabilan politik, seperti kudeta, revolusi, dan pembunuhan politik berkorelasi terbalik dengan pertumbuhan Produk Domestik Bruto (PDB) dan bagian investasi dari PDB. Dia menyimpulkan bahwa ketidakstabilan politik, melalui dampak buruknya terhadap hak milik, mengurangi pertumbuhan dan investasi. Stabilitas politik memengaruhi pertumbuhan ekonomi. Ini disebut "politisasi pertumbuhan ekonomi" (Barro, 1995).

DKI Jakarta memiliki dua wajah dalam eksistensinya. Pertama, DKI Jakarta adalah ibu kota negara. Kontrol pemerintahan atas 34 provinsi di Indonesia dikendalikan dari sana. Kedua, DKI Jakarta adalah pusat kegiatan ekonomi Indonesia (Kearney, 2018). Status ini membuat kedudukan DKI Jakarta sangat penting bagi keadaan ekonomi Indonesia dalam skala nasional. Menimbang dua wajah DKI Jakarta, stabilitas politik adalah sebuah keniscayaan di DKI Jakarta.

Pilgub DKI Jakarta pada tahun 2017 menjadi catatan sejarah baru buat DKI Jakarta. Bisa dikatakan kegaduhan politik yang terjadi bisa 
mengancam dua wajah yang ada di DKI Jakarta. Pilgub DKI Jakarta memang rawan terhadap kegaduhan politik yang bisa berujung pada instabilitas politik. Instabilitas politik ini dalam skala tertentu dapat menyebabkan instabilitas ekonomi yang bukan hanya bisa berdampak pada DKI Jakarta melainkan Indonesia secara keseluruhan.

Catatan sejarah, seperti pilgub DKI Jakarta 2017 bisa berulang lagi mengingat DKI Jakarta merupakan daerah strategis bagi para politisi dan partai politik untuk menancapkan kekuasaan yang lebih tinggi di Indonesia. Mungkin, pilgub DKI Jakarta di masa mendatang bisa menciptakan kegaduhan lain yang bisa jadi bukan dilatarbelakangi oleh gesekan berbasis agama ataupun identitas seperti yang terjadi saat ini. Konflik yang bakal terjadi sangat mungkin berkaitan dengan kepentingan masing-masing pihak yang bertarung nantinya.

\section{Pengangkatan Gubernur DKI Jakarta: Dua Pilihan Alternatif}

Muncul pertanyaan bagaimana teknis pengangkatan gubernur DKI Jakarta jika pemilihan gubernur langsung oleh rakyat ditiadakan. Tulisan ini mengungkap ada dua alternatif terbaik yang bisa dijadikan bahan pertimbangan pada policy makers. Dua alternatif pilihan ini bisa menjadi solusi tentang prosedur pengangkatan gubernur DKI Jakarta.

Dalam artikel ini, prosedur pertama disebut sebagai mekanisme minimum demokrasi prosedural. Dalam hal ini, prosedur demokrasi tetap dilaksanakan namun hanya dalam kadar yang sangat kecil. Mekanisme ini berawal dari pemilihan nama yang diinginkan oleh presiden Republik Indonesia sebagai penguasa eksekutif tertinggi. Presiden bisa menetapkan minimal satu orang nama yang dianggap kompeten memimpin DKI Jakarta. Nama ini kemudian diajukan oleh presiden kepada DPRD DKI Jakarta.

DPRD DKI Jakarta kemudian melakukan uji kelayakan dan 
kepatutan terhadap calon gubernur yang namanya diajukan oleh presiden. Setelah uji kelayakan dan kepatutan tersebut, hasilnya diserahkan kepada presiden sebagai bahan pertimbangan terhadap calon yang diajukan. Atas dasar pertimbangan DPRD DKI Jakarta tersebut, kemudian presiden bisa menetapkan atau memilih (jika calon yang diajukan lebih dari satu) satu orang yang akan menjadi gubernur DKI Jakarta selama lima tahun. Dalam kurun waktu lima tahun tersebut, gubernur DKI Jakarta bertanggung jawab secara penuh kepada presiden. Pertanggungjawaban ini berkaitan dengan sumber mandat yang memang berasal dari presiden. Apabila presiden menginginkan pergantian dalam kurun waktu kurang dari lima tahun, maka presiden dapat memberhentikan gubernur dan mengulangi prosedur pemilihan, seperti yang sudah dijelaskan sebelumnya.

Bagan 1. Mekanisme Minimum Demokrasi Prosedural

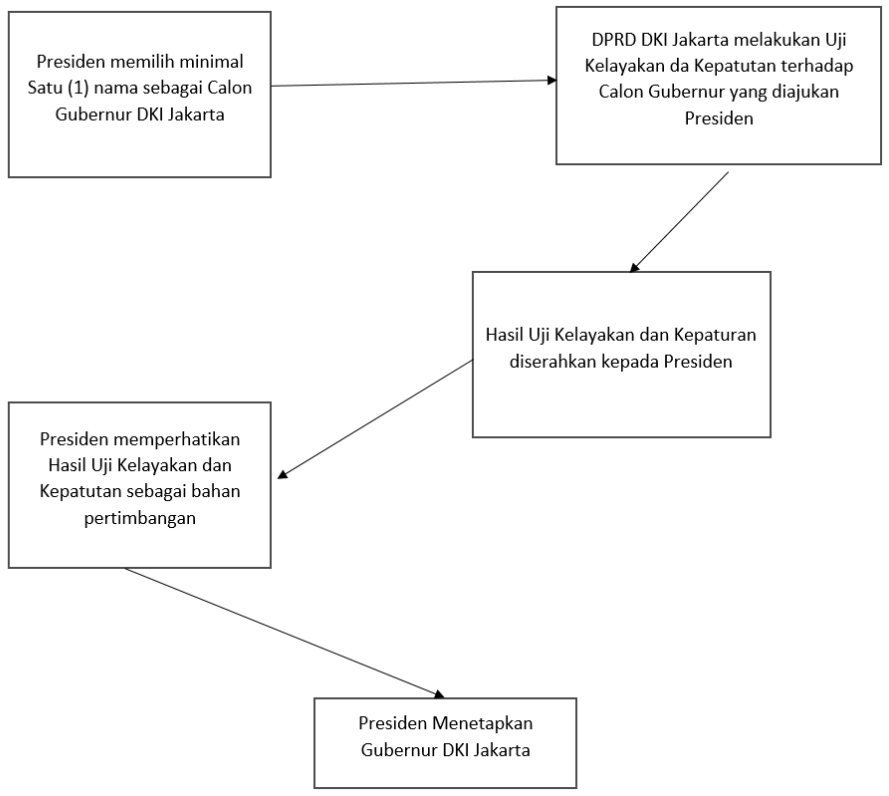


Pilihan alternatif kedua, disebut sebagai zero demokrasi prosedural. Mekanisme ini merupakan mekanisme yang menghilangkan proses demokratis untuk memilih seorang gubernur DKI Jakarta. Mekanisme ini adalah presiden menjadikan jabatan gubernur DKI Jakarta sebagai jabatan setingkat menteri. Dengan ini, maka ada tambahan nomenklatur baru perihal penyebutan gubernur DKI Jakarta, yakni sebagai Menteri Negara Urusan DKI Jakarta. Menteri Negara Urusan DKI Jakarta/Gubernur DKI Jakarta merupakan jabatan politis yang masuk dalam struktur kabinet yang dibentuk oleh presiden. Dalam menjalankan pemerintahan, gubernur DKI Jakarta bertanggung jawab penuh kepada presiden. Seperti pembantu presiden lainnya, gubernur DKI Jakarta bisa diganti kapan saja sesuai dengan kehendak presiden yang menjabat. Peran DPRD DKI Jakarta dihilangkan pada mekanisme ini.

Bagan 2. Mekanisme Zero Demokrasi Prosedural

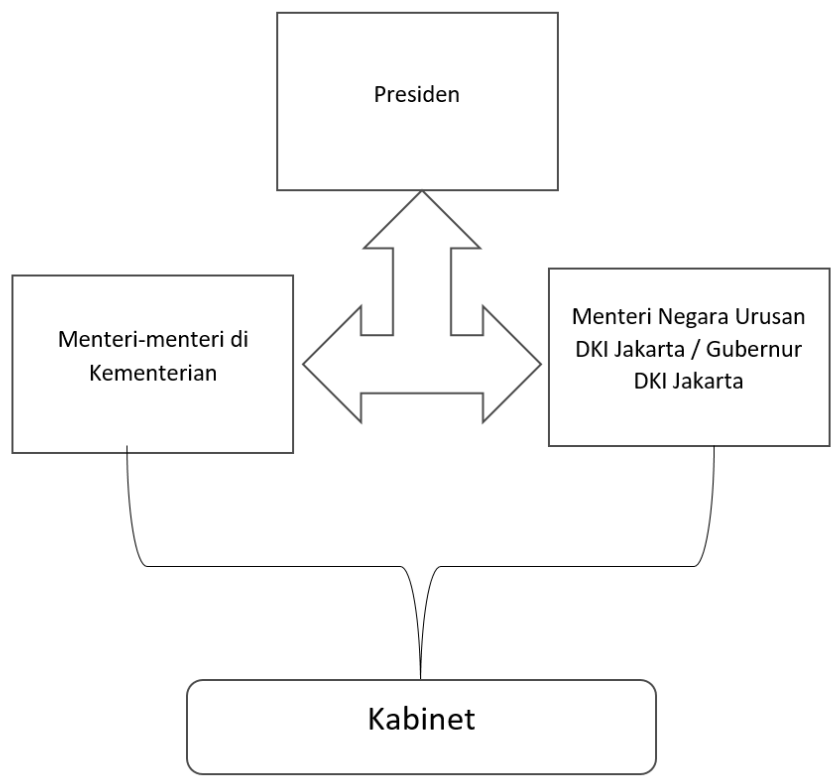




\section{Posisi Wakil Gubernur DKI Jakarta}

Menjadi sebuah pertanyaan ke mana posisi wakil gubernur DKI Jakarta berkaitan dengan argumentasi-argumentasi dalam artikel ini? Tulisan ini tidak ingin menghilangkan posisi dan peran seorang wakil dalam struktur pemerintahan. Posisi wakil gubernur DKI Jakarta juga penting dalam kaitannya dengan membantu kinerja gubernur DKI Jakarta yang memiliki beban kerja tinggi. Argumentasi tulisan ini, pengangkatan wakil gubernur DKI Jakarta bergantung pada mekanisme apa yang akan diterapkan nantinya, apakah itu minimum demokrasi prosedural atau zero demokrasi prosedural.

Pada proses minimum demokrasi prosedural, posisi wakil gubernur bisa diajukan secara bersamaan dengan pengajuan nama untuk calon gubernur DKI Jakarta oleh presiden. Pada saat presiden minimal satu nama untuk calon gubernur DKI Jakarta (bisa lebih), sekaligus presiden juga mengajukan nama untuk calon wakil gubernur DKI Jakarta minimal satu nama (bisa lebih). DPRD DKI Jakarta kemudian juga melakukan uji kelayakan dan kepatutan terhadap calon wakil gubernur bersamaan dengan calon gubernur. Hasil uji kelayakan dan kepatutan tersebutlah yang kemudian diserahkan kepada presiden untuk dijadian bahan pertimbangan.

Pada proses zero demokrasi prosedural, posisi wakil gubernur DKI Jakarta juga turut ditetapkan langsung oleh presiden sebagaimana gubernur DKI Jakarta. Posisi wakil gubernur DKI Jakarta mengikuti status gubernur DKI Jakarta, yakni menjadi Wakil Menteri Negara Urusan DKI Jakarta/Wakil Gubernur DKI Jakarta. Posisi wakil gubernur DKI Jakarta kemudian menjadi sebuah posisi dimana presiden memiliki kuasa penuh untuk mengganti orang yang berada di posisi tersebut. 


\section{Konsekuensi Warga DKI Jakarta}

Dua alternatif pilihan prosedur pengangkatan gubernur DKI Jakarta merupakan sebuah proses yang meminimalisir/bahkan, tidak mengakomodir peran masyarakat secara langsung. Dalam tataran praktis, jika kebijakan ini diterapkan maka akan banyak pro dan kontra. Pro dan kontra adalah sebuah keniscayaan dalam proses implementasi kebijakan. Maka dari itu, pro dan kontra akan hadirnya sebuah kebijakan adalah hal yang biasa terjadi.

Pada dasarnya, banyak pihak di level grassroot mungkin menentang dengan wacana kebijakan ini. Kebijakan pengangkatan gubernur DKI Jakarta oleh presiden akan semakin memangkas rakyat DKI Jakarta untuk berdemokrasi secara langsung, yakni dengan memilih sendiri pemimpinnya. Terlebih lagi jika kebijakan ini diterapkan maka rakyat DKI Jakarta sama sekali tidak punya hak memilih di level eksekutif daerah. Level eksekutif seperti walikota dan bupati di DKI Jakarta adalah pejabat publik yang diangkat oleh gubernur DKI Jakarta. Ini menjadikan masyarakat DKI Jakarta di tingkat daerah hanya mempunyai hak untuk memilih anggota DPRD DKI Jakarta.

Dengan pengangkatan gubernur DKI Jakarta oleh presiden bisa membuat DKI Jakarta dan Indonesia bisa terhindar dari kegaduhan politik yang bisa berujung pada instabilitas ekonomi. Gesekan horizontal antara sesama masyarakat bisa terhindarkan. Polarisasi masyarakat seperti yang terjadi sekarang ini bisa diminimalisir karena DKI Jakarta tidak mengadakan perhelatan pemilihan gubernur yang bisa mengacak sendi-sendi persatuan yang sebelumnya hampir belum pernah terjadi secara terbuka seperti sekarang. 


\section{Kesimpulan}

Wacana pengangkatan gubernur DKI Jakarta oleh presiden yang tanpa melalui pemilihan langsung oleh rakyat merupakan wacana yang patut dipertimbangkan kembali. Kegaduhan politik di Jakarta ditakutkan bisa terulang kembali. Ini berbahaya bagi stabilitas ekonomi Indonesia secara keseluruhan karena posisi DKI Jakarta sebagai ibu kota negara. Gesekan horizontal di level grassroot juga dapat dihindari dan rasa persatuan sebagai saudara sebangsa dapat terjaga seperti sedia kala.

Desentralisasi asimetris di DKI Jakarta diterapkan dengan adanya UU Nomor 29 Tahun 2007 tentang Pemerintahan Provinsi Daerah Khusus Ibu Kota Jakarta. Dalam level praktis, mekanisme pengangkatan gubernur dengan mekanisme minimum demokrasi prosedural dan zero demokrasi prosedural bisa menjadi alternatif pemilihan yang bisa diterapkan di level praktis. Langkah praktis ini bisa dilakukan jika para pemangku kebijakan melakukan evaluasi dan merevisi UU No. 29 Tahun 2007 tersebut. Revisi bisa difokuskan pada proses pemilihan kepala daerah DKI Jakarta seperti yang telah dijelaskan tadi.

Artikel ini berusaha memantik para ilmuwan politik lainnya untuk memikirkan kembali tentang mekanisme pemilihan gubernur DKI Jakarta. Dalam literatur politik, perdebatan perihal mekanisme perebutan kekuasaan adalah hal yang biasa dan bisa dieksplorasi lebih dalam. Artikel ini diharapkan bisa memicu tulisan-tulisan lain yang bisa jadi mendukung, mengoreksi, atau bahkan membantah argumentasiargumentasi yang telah dipaparkan di sini. 


\section{Referensi}

Abdullah, Asyaari. (2017). Membaca Gerakan Aksi Bela Islam 212: Antara Politik Identitas dan Ijtihad Politik Alternatif. Jurnal Annida': Jurnal Pemikiran Islam, Edisi Desember 2017, Vol. 41, No. 2.

Admin. Sejarah DBKL. Diakses dari http://www. d b k l.g o v. m y / i n d e x.p h p ? o p t i o n = c o m _ content\&view=article\&id=39\&Itemid=174\&lang=ms tanggal 29 April 2019.

Ambarita, Biner. (2015). Urgensi Undang-undang Keamanan Nasional Dalam Stabilitas dan Sinergitas Nasional. Jurnal Generasi Kampus, Vol 8, No. 1.

Agustino, L., \& Yusoff, M. A. (2010). Politik Lokal Di Indonesia: Dari Otokratik Ke Reformasi Politik. Jurnal Ilmu Politik, Edisi, 21, 2010.

Alesina, A., Özler, S., Roubini, N., \& Swagel, P. (1996). Political instability and economic growth. Journal of Economic Growth, 1 (2), 189-211.

AT, Kearney. (2018). Sustaining Indonesia's Economic Expansion. Diakses di http://www.iberglobal.com/files/2018/indonesia atkearney.pdf.

Barro, R. J. (1995). Inflation and Economic Growth, NBER Working Paper, 5326.

Buntoro, G. A. (2017). Analisis Sentimen Calon Gubernur DKI Jakarta 2017 di Twitter. Integer Journal Maret, 1 (1), 32-41.

Burhani, Ahmad N. (2016). Aksi Bela Islam: Konservatisme dan Fragmentasi Otoritas Keagamaan. MAARIF, Vol. 11, No. 2. 
Chien, S. (2007). Institutional Innovations, Asymmetric Decentralization, and Local Economic Development: A Case Study of Kunshan in Post-Mao China, Environment and Planning C: Government and Policy, volume 25, pages 269-290. https://doi.org/10.1068/c0558.

Feng, Y. (1997). Democracy, Political Stability and Economic Growth. British Journal of Political Science, 27 (3), 391-418.

Gjoni, R., A. Wetterberg, \& D. Dunbar. (2010). Decentralization as a Conflict Transformation Tool: The Challenge in Kosovo. Public Administration and Development, 30 (5), 291-312.

Hadiz, V. R. (2017). Indonesia's Year of Democratic Setbacks: Towards a New Phase of Deepening Illiberalism? Bulletin of Indonesian Economic Studies, 53 (3), 261-278. https://doi.org/10.1080/0007 4918.2017.1410311.

Ilham, N., \& Siregar, H. (2016). Dampak Kebijakan Harga Pangan dan Kebijakan Moneter terhadap Stabilitas Ekonomi Makro. Jurnal Agro Ekonomi, 25 (1), 55-83.

Kurniadi, B. D. (2009). Yogyakarta in Decentralised Indonesia: Integrating Traditional Institution into Democratic Transition. Jurnal Sosial dan Politik, Vol. 1, No. 2

Kurniadi, B. D. (2012). Desentralisasi Asimetris di Indonesia. Disampaikan dalam Seminar di Lembaga Administrasi Negara Jatinangor tanggal 26 November 2012.

Lay, Cornelis. (2001). Otonomi Daerah dan Keindonesiaan. Jurnal Ilmu Sosial dan Ilmu Politi, Vol.5, No. 2. 
Lim, M. (2017). Freedom to Hate: Social Media, Algorithmic Enclaves, and The Rise of Tribal Nationalism in Indonesia. Critical Asian Studies, 49 (3), 411-427. https://doi.org/10.1080/14672715.2017 .1341188 .

Litvack, Jennie et.al. (1998). Rethinking Decentralization in Developing Countries. Washington DC: The World Bank.

Mcgarry, J, (2007). Asymmetry in Federations, Federacies and Unitary States. Ethnopolitics, Vol. 6, No. 1, 105-116

Nasution, I. K. (2016). The Challenge of Decentralization in Indonesia: Symmetrical and Asymmetrical Debate. International Journal of Social Science and Humanity, 6 (9), 691.

Pamungkas, A. S, Gita Oktaviani. (2017). Aksi Bela Islam dan Ruang Publik Muslim: Dari Representasi Daring ke Komunitas Luring. Jurnal Pemikiran Sosiologi, Vol. 4, No. 2

Prayogi, I. (2018). Populisme Islam dan Imajinasi Politik dalam Pilkada DKI Jakarta 2017. http://repositori.usu.ac.id/ handle/123456789/5942.

Rizal. (2017). Usulan Fahri Hamzah: Gubernur DKI Dipilih Presiden. Diakses dari https://www.idntimes.com/news/indonesia/rizal/ usulan-fahri-hamzah-gubernur-dki-dipilih-presiden/full tanggal 27 April 2019.

Saudale, Vento. (2017). Kemdagri Usulkan Gubernur Jakarta dipilih oleh Presiden. Diakses dari https://www.beritasatu.com/ nasional/453979/kemdagri-usulkan-gubernur-dki-ditunjuklangsung-presiden tanggal 27 April 2019.

Setijadi, Charlotte. (2017). Chinese Indonesians in the Eyes of the Pribumi Public. () ISEAS Yusof Ishak Institute. http://hdl.handle. net/11540/7545. 
Shah, A., \& T. Thompson. (2004). Implementing Decentralized Local Governance: a Treacherous Road With Potholes, Detours, and Road Closures. Washington DC: The World Bank.

Syahputra, I. (2018). Demokrasi Virtual dan Perang Siber Di Media Sosial: Perspektif Netizen Indonesia. Jurnal ASPIKOM, 3 (3), 457. https://doi.org/10.24329/aspikom. v3i3.14.

Utomo, T.W.W.(2009). Balancing Decentralizationand Deconcentration: Emerging Need for Asymmetric Decentralization in The Unitary States. 名古屋大学 Discussion paper, 174, 1-30.

Wilson, I. (2017). Jakarta: Inequality and the Poverty of Elite Pluralism. New Mandala, 1-8.

Younis, Muhammad et.al. (2008). Political Stability and Economic Growth in Asia. American Journal of Applied Sciences, Vol. 5, No. 3. 